


\section{Online folyóirat}

Szerkesztette: VÁGÁNY Judit Bernadett, PhD - FENYVESI Éva, PhD

Borító: FLOW PR

Kiadja: Budapesti Gazdasági Egyetem, Kereskedelmi, Vendéglátóipari és Idegenforgalmi Kar, Közgazdasági és Üzleti Tudományok Tanszék

Felelős kiadó: FENYVESI Éva, PhD

a Közgazdasági és Üzleti Tudományok Tanszék vezetője

ISSN 2630-886X

2019. 


\title{
A HUNGARIKUM, MINT ENDOGÉN ERŐFORRÁS SZEREPE A HELYI FEJLESZTÉSBEN, A GÖNCI BARACKPÁLINKA PÉLDÁJÁN KERESZTÜL
}

\author{
THE ROLE OF HUNGARICUMS AS ENDOGENOUS \\ RESOURCES IN LOCAL DEVELOPMENT THROUGH THE \\ EXAMPLE OF GÖNCZ APRICOT PALINKA
}

RITTER Krisztián

Kulcsszavak: endogén eróforrás, helyi gazdaságejlesztés, mezógazdaság, vidékfejlesztés Keywords: agriculture, endogenous resources, local economic development, rural development

JEL kód: $A 19$, Q19, R59 


\section{ÖSSZEFOGLALÓ}

Miköz̧ben az elmúlt évtizedekben a belyi eröforrások szerepe a terület-és vidékfejlesżtésben határozottan elótérbe került, a számos településen, térségben korábban föszerepet játszó agrárium gazdasági/társadalmi súlya jelentösen csökkent. A Szent István Egyetem Regionális Gazdaságtani és Vidékfejlesztési Intézete (RGVI) évente szervez vidéki térségekre irányuló kutatásokat, melyek során többek közt az agrárium és az élelmiszertermékek helyi fejleszutési stratégiában betölthetö szuerepét vizsgáljuk. Hipotézisünk, hogy az. endogén forrásokra épülō gazdaságfejlesztés számos hazai kistérség esetében kitörési pontot jelenthet a hosszú távú fejlesztések terén. Ennek vizsgálata az itt ismertetésre kerülö kutatás kapcsán a Magyar Értéktárban nyilvántartott eredetvédett gönci barackpálinka terïleti hatásaira fókuszálva történt. A gyüjtött szek.under adatok mellé 2014 tavaszán mélyinterjúk készülttek a vizsgált hungarikum elöállitásában, gondozásában

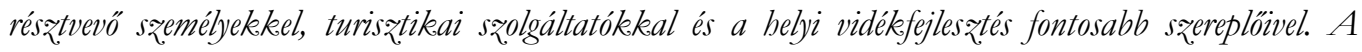
kutatási eredmények igazolták, hogy a bungarikumok elóallitása számos közvetlen és közvetett haszonnal jár a vizsgált térségek társadalmának és gazdaságának egészére. Hozzájárul többek között a belyben történó munkahelyteremtéshez és megörzéshez, a belyi vendéglátás és turizmus serkentésébez, az alapanyag elöállitók. és a szeszfỡ dék bevételeinek, és igy a belyi adóbevételek növekedéséhez. Emellett a kiváló minöségü terméke.k diverzifikációs lehetöséget nyúitanak a helyi gazdálkodók számára, továbbá a hungarikum védjegy hozzájárul a vizsgált térségek ismertségének növeléséhez. is. A vizsgálat azonban arra is rávilágitott, hogy nagyobb figyelmet kellene belyezni országosan és helyi szinten is az endogén forrásokra alapozott kézmüves termékek értékteremtésére, helyi gazdaságfejlesz̧tési lehetöségeikere.

\section{SUMMARY}

The role of the endogenous resources has been emphasized since a long time by the literature of territorial and rural development. In parallel the role of agriculture in local employment has decreased significantly for the last few decades. The Institute for Regional Economics and Rural Development (IRERD) of the $S_{\text {zent }}$ István University Gödöllö regularly makes researches in traditionally farming rural areas to analyze the possible role of agriculture and food products besides such tendencies in local development strategies. The paper focuses on the territorial effects of Göncz apricot Pálinka as Hungaricum product (being under protection of origin registered in the Hungarian Repository of $V$ alues). After secondary data collection, in-depth interviews with people who took part in the production and management of the examined Hungaricum, tourism providers and the most important actors of local rural development were conducted in the spring of 2014. The research proved that the production of Göncz Palinka has made several direct and indirect benefits for the economy and society of the examined micro region. It has contributed among other things to the local job generation and preservation, stimulation of catering and tourism, growth of income of producers of raw materials and distilleries and so to the increase of local tax revenues. In addition, the premium-quality product has provided diversification opportunities for local farmers. However the research has highlighted that this endogenous resource should be even deeper exploited in the future. To achieve this aim further national and local interventions and subsidies would be necessary. 


\section{BEVEZETÉS}

A világgazdaságban lejátszódó folyamatok, a globalizáció alapvető következménye, hogy a versenyképesség feltételeinek a kialakítása az endogén fejlődéselméletek, a saját erőből történő építkezés előtérbe kerülésével, az egyes települések, térségek feladatává is vált. Lényeges elem a vidék fogalmának megerősödése, átalakulása, új szerepkör betöltése is, hiszen a Közös Agrárpolitika célkitűzésein és intézkedésein keresztül már világosan tetten érhető a mezőgazdaságnak és a vidéknek tulajdonított multifunkcionális szerepkör. A multifunkcionalitás alapgondolata szerint a vidéki népesség jövedelme nem kizárólagosan csak az elsődleges funkcióból, élelmiszer és ipari nyersanyag-termelésből, hanem a kulturális és környezeti feladatok ellátásából is származik, miközben megváltoznak a vidéki tér és a gazdálkodás formái is (ld. Bretagnolle et al. 2018). A mezőgazdálkodás európai modelljében a többfunkciós mezőgazdaság és az annak helyet adó vidék az élelmiszer-termelés mellett ökológiai-környezeti, valamint társadalmi-, gazdasági-, szociális-, kulturális funkcióját is betölti. Ide tartozik többek közt a rekreáció és a turizmus feltételeinek megteremtése, a kisés középvállalkozások támogatása, a vidéki közösségek ápolása, a tájképi és népi kulturális örökség fenntartása, a hagyományok ápolása, az agrár-környezetvédelem (Marsden és Sonnino, 2008).

Hazánkban is rendkívül fontos szerepet kapnak a lokális, endogén erőforrások, mint az önerőből történő építkezés alapkövei. Kiemelt fontosságot szerzett azoknak a tényezőknek a meghatározása, felkutatása, megszerzése vagy kialakítása, melyek egy-egy terület „önálló” gazdasági-társadalmi fejlődéséhez, fejlesztéséhez, mint kiinduló kínálati elem járulnak hozzá. A hungarikumok, mint sajátos, egyedi és versenyképes erőforrások területi fejlődésben betöltött/betölthetô szerepét (területi jelentőségét), a helyi fejlesztésekkel és endogén elméletekkel kapcsolatos szakirodalom, valamint a vonatkozó kutatások is körvonalazzák (ld. pl. Ritter, 2017; Tóth et al., 2017).

A hungarikum olyan megkülönböztetésre, kiemelésre méltó magyar nemzeti érték, amely több évszázada vagy nemzedékek során, vagy akár a közelmúltban történt létrejötte révén a történelmi és a mai Magyarországra jellemző mivoltával, egyediségével, különlegességével és minőségével a magyarság szimbólumává vált. Továbbá belföldön és külföldön egyaránt tükrözi a magyarsághoz tartozást, valamint, amelyet az e törvény végrehajtására kiadott jogszabályban meghatározottak szerint végzett egyedi értékelés eredményeként a Hungarikum Bizottság (HB) hungarikummá minősít, vagy amely e törvény erejénél fogva hungarikumnak minősül. A Hungarikumok Nemzeti Gyűjteménye a nemzeti értékek köréből a HB által hungarikummá nyilvánított, valamint e törvény erejénél fogva hungarikumnak minősüő nemzeti értékek gyüjteménye.

Nemzeti Érték az a sajátpsan magyar szellemi-termelő tevékenységhez, termelési kultúrához, tudáshoz és hagyományokhoz kapcsolódó szellemi, termelő vagy múvészeti tevékenység eredményeként létrejött egyedi, különleges produktum, valamint azon egyedi, különleges természeti érték, amely hazai szempontból meghatározó jelentőségű, így a magyarországi lakosság - de legalább egy meghatározott tájegység lakossága - magyarságra jellemzőnek és 
közismertnek fogad el, és amely külföldön is magyar sajátosságként ismerhető és ismertethető meg. (2012. évi XXX. törvény)

Jelen tanulmány a vizsgált pálinka országimázsban való felhasználhatóságát, valamint a gönci barackpálinka szélesebb értelemben vett területi hatásait tárja fel, de nem a keresleti, hanem a kínálati oldal, tehát a termelők, az előállítok, és a termék/szolgáltatás mixet befolyásoló térségi szereplők szemszögéből.

\section{SZAKIRODALMI HÁTTÉR}

A világgazdaságban lejátszódó folyamatok, a globalizáció, az európai gazdaság térszerkezetének átrendeződése, az utóbbi évtizedekben a területi politika felértékelődéséhez vezetett. A területi egyenlőtlenségek mérséklését szolgáló célok mellett egyre nagyobb súllyal szerepelnek az európai gazdasági tér versenyképességének erősítését szolgáló intézkedések. A versenyhez való alkalmazkodás képessége végső soron az, amely egy-egy terület helyzetét, fejlődési esélyeit és lehetőségeit alapvetően befolyásolja (ld. többek közt Chesire, 2003; Horváth 2006; Lengyel, 2003 vagy Rechnitzer és Tóth, 2014). Lényegében „az új területi politikák homlokterébe a térségek, régiók adottságai, potenciáljai kerültek, melyek a fejlesztésekhez, mint belső, endogén erőforrások állnak rendelkezésre, és megfelelő körülmények közt aktivizálhatók" (Káposzta, 2007: 89. o.).

A világgazdaság globalizálódásának fokozódása, a kiéleződő területi verseny, az egyre komplexebb üzleti környezet megteremtésének fontossága előtérbe helyezik az adott térség szereplőit összefogó és koordináló, alulról építkező, kifejezetten a helyi erőforrásokra építő helyi gazdaságfejlesztési stratégia kidolgozásának, megvalósításának igényét. Ez kifejezetten vidékfejlesztési szempontból is értelmezhető, hiszen az Unió vidékpolitikájának megfelelően, „a szélesebb vidéki gazdaságra vonatkozó intézkedéseket lehetőleg helyi fejlesztési stratégiákon keresztül kell végrehajtani” (EC, 2005: 5. o.).

Az endogén elmélet szerint ezek a fejlesztések akkor lehetnek eredményesek, ha egyértelműen az adott terület helyi (természeti, gazdasági, humán, kulturális) erőforrásaira alapoznak (Kulcsár, 2017). Murdoch (1995) szerint eközben az önerős fejlesztés révén hosszú távon elszakadnak a külső támogatás okozta függőségtől, és a fenntartható fejlődést szolgálják. Terluin és Post (2001), valamint Kulcsár (2017) alapján a helyi erőforrások (local resources) mellet, a helyi tevékenységek (local activities) és a helyi szereplők (local actors) fontossága, valamint az integrált megközelítés is meghatározó.

Moseley (2003) alapján a helyi erőforrások értékének előnyben részesítése az importált nyersanyag és tôke preferálása helyett biztonságosabb és fenntartható jövőt teremt a gazdasági fejlesztés számára. Ehhez a helyi erőforrások, valamint ezeknek az új üzleti lehetőségek megteremtésére való potenciáljának ismerete, és a megfelelő hozzáértés szükséges. A helyi erőforrások helyi igénybevétele biztosítja, hogy a beléjük fektetett tőke a területen belül marad és újrahasznosul. Ezen túl a helyi sokszínúség szándékos hangsúlyozása és hirdetése, a helyi terület jellegzetességeinek támogatása, a helyi identitás, valamint a hozzá kapcsolódó különféle minőségi áruk és szolgáltatások fejlesztése és értékesítése a globalizációval szembeni védelmet is jelenti. 
Az endogén fejlesztések alapjait jelenthetik tehát a helyben elóállított, az adott téregységre jellemző termékek. Belletti és társai (2003) alapján a helyi termékek kapcsolódását egy adott térség vidékfejlesztéséhez az biztosítja, hogy ezen termékeket az előállítási helyszínükkel való szoros kötődés teszi igazán egyedivé, amely a keresletüket is nagymértékben befolyásolja. Így az érintett vidéki területeknek egyfajta potenciális erőforrásként kell tekinteniük ezekre a termékekre. Endrighi (1999) szerint a helyi, egyedi termékek alapvetően kétféle módon befolyásolhatják előállítási helyük környezetét: a) a termék sikere gazdasági hasznot hoz az azt elóállító vállalkozások számára, illetve a termék ismertségének növekedése magával húzza a helyi gazdaság egyéb szereplőit is (pl.: idegenforgalom, vendéglátás és kézművesség); b) a termék sikere többnyire csak a helyi lakosság bevonásával érhető el (pl.: munkaerőként alkalmazva), amely magával vonja a társadalmi kohézió és az identitástudat erősödését is.

Pacciani és társai (2001) megállapítják, hogy a helyi, különleges termékek értéknövelésében érdekelt szereplők nagymértékben különbözhetnek egymástól, és mindegyik fél a saját érdekét tartja szem előtt. Egyes szereplők közvetlenül is részt vesznek a termék előállításában, míg mások csak közvetett szerepet töltenek be, esetenként nem is az előállítás helyszínén tevékenykednek. A szereplők érdekeltségeit alapvetően az határozhatja meg, hogy az érintettnek mi a célja, illetve hogy önmagának a régiónak, mint a termék elóállítási helyszínének milyen szerepet jut. Az érintettek célja alapján megkülönböztethetünk olyan stratégiát, amely csak magának a terméknek az előállítási és értékesítési folyamatára (az ellátási láncra) koncentrál, illetve olyat, amikor a helyi gazdaság és társadalom egésze a célcsoport (kiterjesztett nézőpont). Az előállítási helyszín a stratégiában betöltött szerepe alapján lehet egyszerűen csak egy minőségi ismertetőjel, de akár az adottságok kifejezője is. Minőségi ismertetőjelként (garanciaként) a származási hely pontos megjelölése arra szolgál, hogy segítsen a vásárló számára megkülönböztetni az adott terméket a többi, hasonló terméktől. Adottságok kifejezőjeként az előállítási hely egy gyűjtőfogalom, mely a régióhoz kötődő összes termék- és szolgáltatás-kosarának együttesét fejezi ki. A termék szoros értelemben vett ellátási lánca mellett figyelmet szán a kapcsolódó ágazatoknak is, és általánosságban véve szolgálja az adott térség érdekeit (idézi Török 2013).

Vidékfejlesztési szempontból - bár mindkét stratégia generál pozitív hatásokat - a termék adottságaira koncentráló megközelítés irányából az adott térség adottságaira koncentráló stratégia irányába való elmozdulás hozhat szélesebb értelmú területi fejlődést.

A települési, tájegységi, megyei és ágazati értéktárba sorolt elemek sajátos, egyedi, endogén, és nemzetközi szinten értelmezhető erőforrásként való értelmezése megkérdőjelezhetetlen. Az agrár- és élelmiszergazdaság területén fellelhető hungarikumok - így pl. a földrajzi árujelzôs EU oltalom alatt álló gönci kajszibarack, és a belőle készült pálinka - keletkezése, megjelenése elsősorban a vidéki térségekhez köthető, így az endogén elméletek, valamint a versenyképességi megközelítések szempontjából is egyértelműen a belső erőforrásokra építő vidékfejlesztési tevékenységek és vidékstratégiák alapja lehet. Az EU és Magyarország vidékstratégiájában megfogalmazott célokhoz, a szélesebb értelemben vett, diverzifikált vidéki gazdaság megteremtéséhez, fenntartásához a hungarikumok a verseny- és piacképesebb mezőgazdasági termék-előállításon, a minőségi élelmiszer termelésen, a 
hagyományos ökoszisztémák fenntartásán, a táji-, természeti-, és kulturális örökségünk megőrzésén, a foglalkoztatás bővítésén, illetve legintegráltabb módon a vidéki turizmuson keresztül járulhatnak hozzá (Ritter, 2013).

Tózsa és Zátori (2013) megállapítják, hogy fontos a hungarikumok turisztikai termékbe való integrálása, ugyanis olyan értékeket és egyben turisztikai erőforrásokat, vonzerőt vagy vonzerő-elemet jelentenek, amelyekre alapozva egyedi, autentikus, újdonságértékkel rendelkező, megkülönböztethető desztinációs termékek hozhatók létre.

Ugyanakkor a hungarikum, mint turisztikai erőforrás önmagában nem kizárólagos sikertényező. Megfelelőképpen kommunikálni is kell a fogyasztók irányába. Az információ szolgáltatás kulcsfontosságú tényező az egyedi érték megtalálásában, valamint a hungarikumok turizmus általi népszerűsítésében egyaránt. A belföldi szegmens (és a határon túli magyarok) irányába a hungarikum, mint brand és kiemelt érték kommunikációján van a hangsúly, a külföldi szegmens tekintetében inkább a hungarikumok bevonásával történő termékfejlesztés a fontosabb, amely megkülönbözteti a hazai ajánlatot a nemzetközi turisztikai piacon (Tózsa és Zátori 2013).

Fentiek alátámasztották annak fontosságát és szükségszerűségét, hogy egy olyan jelentős hungarikum, mint a gönci barackpálinka szélesebb értelemben vett területi hatásait részletesen megvizsgáljuk.

\section{ANYAG ÉS MÓDSZER}

A bevezetőben ismertetett célok elérését a Szent István Egyetem Regionális Gazdaságtani és Vidékfejlesztési Intézetének koordinálásában lefolytatott kutatás szekunder és primer adatok gyűjtésével, elemzésével célozta megvalósítani. A vizsgálat földrajzi kiterjedése a gönci barackpálinka eredetvédettsége által érintett településekre (ld. 1 ábra), illetve az azokat összefogó szervezetek területére szorítkozott. A szekunder adatgyūjtés a rendelkezésre álló statisztikai adatok és helyi fejlesztési dokumentumok bevonására irányult, melyek forrása a KSH (kiemelten a T-Star adatbázis, az ÁMŐ 2000 és 2010), valamint az érintett helyi Leader akciócsoportok (HACS) vidékfejlesztési helyzetelemzései, helyi (vidék)stratégiái (HVS) voltak.

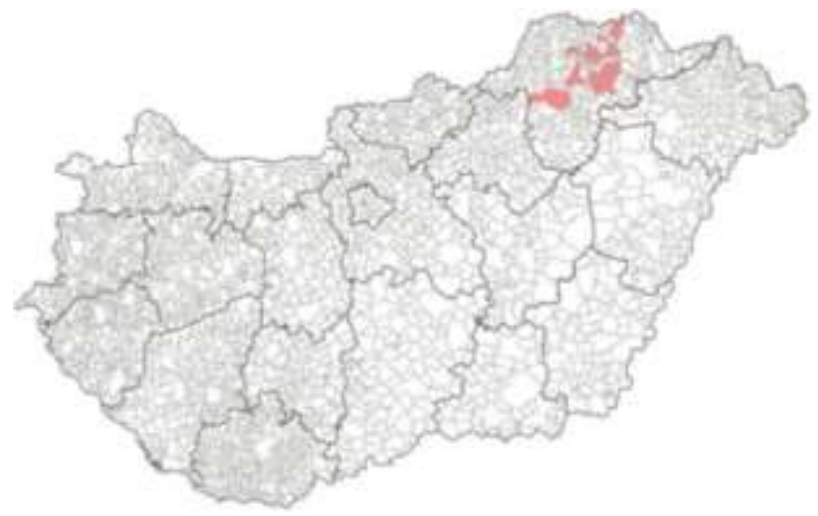

1. ábra. A gönci barackpálinka földrajzi eredetvédelme alá eső területek

Forrás: Saját szerkesz̨tés, 2019 
A primer adatok forrása a gönci barackpálinka, mint helyi hungarikum termékláncának szereplóivel, a helyi fejlesztési tevékenységet összefogó Leader akciócsoportok munkaszervezeteinek vezetőivel, illetve a turisztikai szolgáltatókat összefogó és koordináló helyi együttmúködések, Turisztikai Desztináció Menedzsment (TDM) szervezetek vezetőivel készült strukturált interjúk anyaga. Az interjúkra 2014 februárjában és márciusában került sor az érintett szereplók és szervezetek felkeresésével. A kutatás során a területileg illetékes három akciócsoport, öt turisztikai és egy gazdasági szervezet, 21 pálinkaelőállító vállalkozás kerestük meg, illetve interjú készült a térség országgyúlési képviselőjével is. Jelen anyag kifejezetten a primer kutatás eredményeinek bemutatására koncentrál.

\section{EREDMÉNYEK}

\section{A bungarikum hatásai - fỡzdék}

Arra az első, teoretikus kérdésre, hogy vajon a gönci barackpálinka jogosan került-e be a hungarikumok közé, az összes válaszadó - függetlenül attól, hogy főzde, turisztikai vagy egyéb térségi szervezet képviselője volt-e - egyöntetűen igennel felelt.

A megkérdezett fózdék túlnyomó részt hagyományos, kisüsti eljárást (legalább kétszeres lepárlást) alkalmazó főzdék, az általános kapacitás az 500 literes főzőüst volt. A főzdék jellemzően az utóbbi 20-25 évben, és elsősorban önerôből alakultak, de több is a rendszerváltás előtti közösségi főzde volt, illetve még annál is korábban (1916-ban, 1944ben) létesült.

A megkeresett főzzék közül csupán három cég négy fơzdéje foglalkozott (a kutatás idején) kereskedelmi célú termék-elóállitással (tehát aki tarthat és adhat el pálinkát):

- Boldogkő-Fruit Kft. - Bestillo termékek

- Fôzőmesterek Kft. - Szóráth termékek

- Miskolci Likőrgyár Zrt. - Prekop termékek

A három cégből kettő a modernebb, tornyos technológiát, egy cég a kétlépcsős kisüsti eljárást használja. Ebben a vonatkozásban tehát a közvetlenül hungarikum eredet-megjelöléssel, ennek megfelelő ellenőrzéssel és tanúsítással rendelkező „gönci barackpálinkát” ez a három cég állít elő. Ugyanakkor meg kell említeni, hogy a megkérdezett fơzdék közül több is tervezi (vagy már megszerezte az engedélyt rá) a kereskedelmi célú tevékenységet, és ezen belül az eredetvédett termék elő́llítását. Ennek vannak többletköltségei (elsősorban a jobb minőségú alapanyag-beszerzés, és az eredetvédelemhez kapcsolódó szabályozások végrehajtásából/ellenőrzéséből adódóan), ami esetenként megkérdőjelezheti kisebb cégek vonatkozásában az eredetvédett termék elóállításának rentabilitását, de a személyes benyomások alapján inkább az ez által (vagy a termék reklámértéke által) realizálható többletbevételek mégis vonzóvá teszik ezt a lehetőséget. Fontos megállapítani azt is, hogy a válaszadók véleménye alapján a térségi bérfőzdék (tehát akik csak más cefréjéből főznek, de nem tarthatnak és adhatnak el pálinkát) a helyi minőségi alapanyag helyi, és hagyományos feldolgozásával pontosan ugyanolyan hungarikum jellegú terméket állítanak elő, melyet az 
előírások a NÉBIH ellenőrzésen keresztül csak a kereskedelmi főzdék számára engedélyeznek hivatalosan.

A többi főzde (a megkeresettek 4/5-e) mindegyike kisüsti eljárással csupán bérfőzési tevékenységet végez. A hungarikum termék kereskedelmi értékesítéséből így jelenleg csak a korábban felsorolt cégek részesednek közvetlenül realizált árbevétellel. Az értékesítés jellemzôen a térségen kívüli piacokat céloz meg (kiemelhető Budapest, mint fô értékesítési piac), de a pálinkák a helyi értékesítési pontokon (a háromból kettő cégnek van saját is), illetve kereskedelmi láncok révén esetenként országszerte is megvásárolhatók. Az értékesítés fő színtere a hazai piac, a külföldi értékesítés elenyésző. A válaszadók véleménye alapján a fogyasztás tekintetében is 80-90\%-ban a belföldi részesedés a jellemző.

A kicsi, illetve bérfőzdék jellemzôen családi vagy kisvállalkozásként üzemelve, 2-5 főnek adnak - sokszor idôszaki - munkát, de a nagyobb kereskedelmi főzdék is csak 8-10 ember munkahelyét jelentik.

Az alapanyag, melyből a főzdék a pálinkát előállítják, elsősorban (71\%-ban) az adott főzde közvetlen települési környezetéből, illetve ezen túlmenően a gönci barackpálinka esetén az eredetvédettséggel rendelkező térségből származik (ez a bérfőzdék esetén is így van, hiszen a kereskedelmi célú hungarikum-előallítás során ez nem is lehetne másképpen).

A térség főzdéinek alapanyaga - illetve ezen keresztül az előállított termékek körében - nem csak a barack található meg. Az alapanyagok közt kiemelhető még az alma, szőlő (törköly), szilva, megy, cseresznye, körte és a bogyósok is. Az Encsi és Gönci járások területén múködő főzdék termelésében a gönci barackból előállított pálinka sokkal hangsúlyosabb (itt a barackpálinka termelésben betöltött aránya 30-70\% között mozog), az ezektôl a termőterületektôl távolodva, a többi kistérségben már jóval kisebb fajsúlyú (esetenként az 5\%-ot sem haladja meg). Az egy főzde által átlagosan egy évben elóállított barackpálinka mennyisége 8-15 ezer liter körül mozog.

A kereskedelmi célú főzdék rendelkeznek állandó beszállítókkal, vagy saját alapanyag termeléssel, a bérfőzdék esetében - egy-két esettől eltekintve - nem jellemző a saját alapanyag feldolgozása. A beszállítók és a főzetők esetében is beszélhetünk egy állandó körről, a főzetôk esetében a szám természetesen az évjárattól, terméstől függően bővülhet, változhat. Az egy főzdére eső átlagos főzetések száma 1100-1500 körül alakul évente.

Arra a kérdésre, hogy a gönci barackpálinka hungarikummá válása volt/van-e hatással a főzde tevékenységére, 100\%-ban igen volt a válasz, eltérést csak ennek a hatásnak a nagyságrendjét, vagy közvetlenségét illetően tapasztaltunk. Gyakorlatilag a fözdék szempontjából a hungarikummá nyilvánítás egyfajta reklámként, figyelem-felkeltôként volt érzékelhető, ami kismértékben a főzetett mennyiségben (illetve a barack, mint alapanyag összes feldolgozott alapanyagban való arányában), jelentősebben a barackpálinka iránti növekvő keresletben realizálódik, másrészt pedig a bérfőzdékben előállított pálinka, pontosabban az annak alapjául szolgáló, beszállított cefre határozott minőségi javulásában figyelhető meg. A gönci barackpálinka, mint kiemelt hazai és helyi termék, a térségi termelők és főzetők öntudatának, patriotizmusának, büszkeségének a táptalaján, a nem kereskedelmi forgalomba kerülő pálinkák minőségi javulását is erôsítette, és ez a minőségileg egyre javuló, 
egyre népszerűbb helyi termék áttételesen a helyi lakosok, termelők gazdasági lehetôségeit is szélesíti, erősíti. Ugyanakkor elmondható, hogy a többi, másfajta gyümölcsből készült pálinkák esetében is tetten érhetô a színvonal emelkedése, de leglátványosabban ez a vizsgált termék vonatkozásában észlelhető.

Közvetlen, direkt hatást, például a termelés egyértelmú növekedését, ebből kiinduló foglalkoztatás növekedést, az ár vagy a minőség gyökeres megváltozását nem észlelték a pálinka elő́llítok a hungarikummá nyilvánítás óta.

A térségi főzdék gyakorlatilag a közvetlen környezetük, de szinte a szélesebb értelemben vett, eredetvédettséggel rendelkező térség valamennyi fơzdéjét ismerik, hallottak róla. A többi főzdével való viszonyt gyakorlatilag mindenki „,normálisként” aposztrofálta, bár konkrét együttmúködés (például közös alapanyag felvásárlás, marketing, érdekképviselet stb.) a válaszadók alapján nem valósult még meg. Mindemellett, a megkérdezett főzdék 28\%-a az információ-cserét jelölte meg, mint valamilyen fajta együttműködés.

Megkérdezve, hogy a többi főzdén kívül van-e konkrét együttmúködés a térség bármely turisztikai szolgáltatójával, turisztikai szervezetével, a helyi önkormányzattal, vagy az adott település alapján illetékes helyi Leader akciócsoporttal, a válaszok alapján - bár az általánosan jó kapcsolatokat itt is meg lehet említeni - konkrét, adott célú együttmúködés nem sok esetben érhető tetten a főzdék és a jelzett térségi szereplők közt (2. ábra). Az önkormányzattal való együttmúködést csak egy főzde konkretizálta, a helyi Leader csoporttal vagy adott turisztikai szolgáltatókkal való kooperációt csak minden hetedik fózde jelölte meg. Ugyanakkor személyes véleményünk alapján, a felsorolt szereplők és a főzdék közötti informális kapcsolatok alakulása jó kiinduló pontja lehet a későbbi, konkrét együttmúködéseknek.

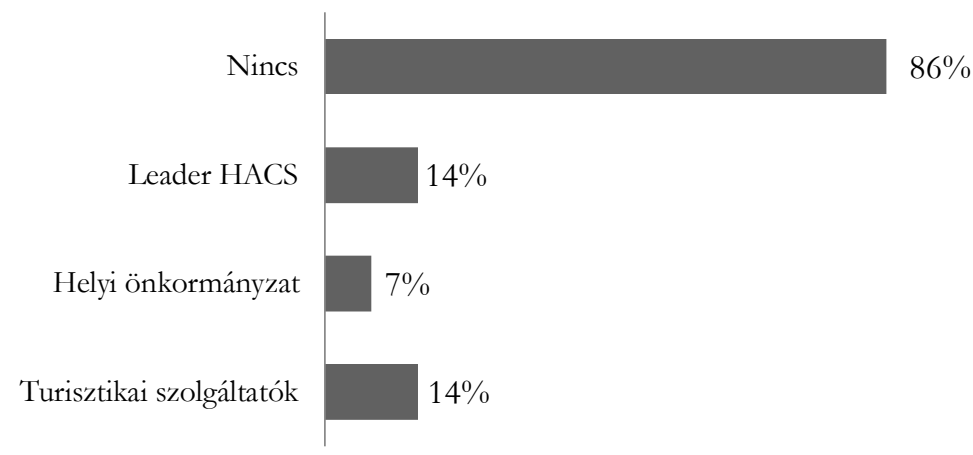

\section{2. ábra. Együttmüködő partnerek megoszlása a megkérdezett főzdék esetében (\%) Forrás: Saját kutatás (2014) és szuerkesztés, 2019}

\section{A bungarikum hatásai - turisz̧tikai szervezetek, Leader}

A vizsgált térségben működő turisztikai szervezetek és együttmúködések az érintett települések önkormányzatait, szállásadóit, turisztikai szolgáltatóit fogják össze (jellemzően 60-100 taggal szervezetenként). A vizsgált szervezetek kifejezetten és konkrétan magát a gönci barackpálinkát, mint hungarikumot nem használják önállóan a tevékenységük során. 
A hungarikum termék közvetetten, a turizmus kínálati mix részeként jelenik meg, elsősorban gasztronómiai elemként, illetve a ráfonódó rendezvények, események kapcsán. A termék turizmust erősítő hatását egyébként az összes megkérdezett szereplő egyértelmúen megerősítette, bár jellemzően a turisztikai szervezetek válasz-arányaival (ld. 3. ábra) megegyezően (75\%-os arányban) inkább az áttételes hatásait, és a kínálat bővítést emelték ki, míg csupán minden negyedik válaszadó gondolta úgy, hogy a térség egyik fő turisztikai eleme, vagy azok közé sorolható.

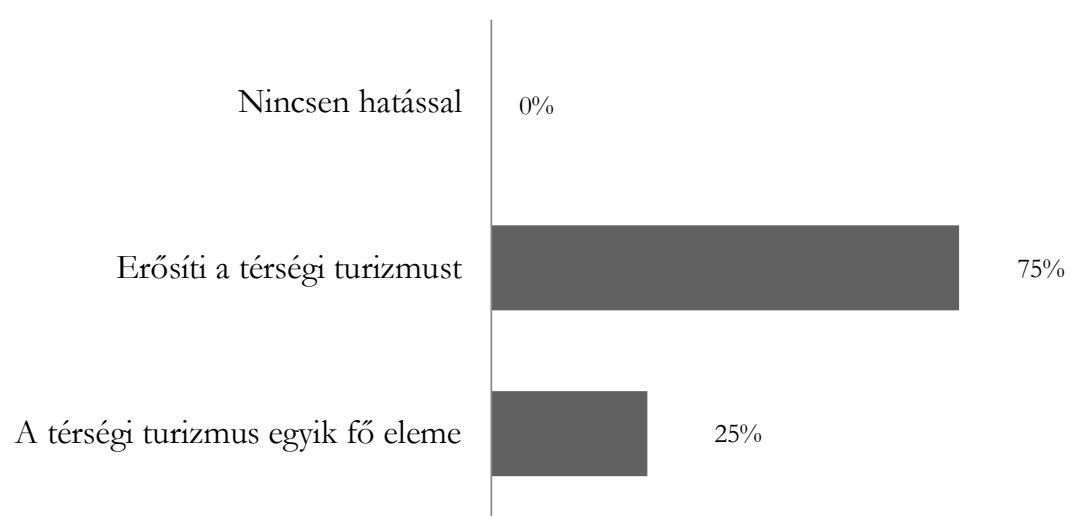

\section{3. ábra. A turisztikai szervezetek megítélése a gönci barackpálinka turisztikai hatásairól (\%)} Forrás: Saját kutatás (2014) és szerkesztés, 2019

A turisztikai válaszadók megerősítették a főzdékkel készült interjúkban is elhangzottakat, miszerint az általánosan meglévő jó viszony mellett nem jellemző a konkrét együttműködés a turizmus aktorai, és a pálinka előállítok közt. A kereskedelmi főzdék, elvétve egy-egy bérfőzde és a környező településeik vonatkozásában találkozhatunk bizonyos szervezett kooperációval (kóstoltatás, főzde látogatás, a főzde termékeinek értékesítése, főzetés), de ezek száma korlátozott. Itt is elhangzott azonban, hogy a térségi rendezvények, turisztikai események vonatkozásában a vizsgált pálinka megjelenése és szerepe körvonalazottabb.

A vizsgált szervezetek mindegyike megerősítette, hogy a helyi fejlesztési programok kidolgozásakor lehetőséget és részvételt kapott, a helyi akciócsoportokkal ápolt viszonyt jónak minősítették, bár - értelemszerűen a tevékenységükből is következően - a turisztikai vonal további erősítését szívesen látnák.

A térségben a bor-utakhoz mérhető attrakció nincs, igaz, ahhoz hasonló, két napos „,pálinkatúra" már megjelent, melynek továbbfejlesztése, kiterjesztése megfontolásra érdemes. Szintén megemlíthető egy - a határon is átnyúló - tanösvény kialakítása is, mely a tervek közt szerepel.

A helyi fejlesztési stratégia kidolgozásakor az érintett Leader térségek közül kettő, az Abaúj Leader Egyesület és a Dél-Zempléni Vidékfejlesztési Szövetség egyértelműen számolt a gönci barackkal, és a belőle készült pálinkával, mint endogén erőforrással és helyi termékkel. A Helyi Vidékfejlesztési Stratégiákban ez tetten érhető, és a két HACS közül az elsőben ez úgynevezett zászlóshajó funkcióként is nevesítve van. A Borsod-Torna-Gömör Egyesület 
csekély érintettségénél fogva már nem kezelte külön a vizsgált termék helyi stratégiában játszott szerepét.

A két igazából érintett akciócsoportban a vizsgálat időpontjáig négy darab, a pálinka előállításhoz köthető pályázatot támogattak, melyek a helyi termék előállítás kapcsán gépbeszerzést, technológia fejlesztést és felújítást szolgáltak a jellemzően kereskedelmi célú főzdék számára. A kisebb kapacitású, illetve bérfőzdék pályázati aktivitása nem észlelhető az akciócsoportok tevékenységében.

A támogatásokkal kapcsolatban a pályázati lehetőségek és források bővitését, kis értékű támogatások lehetőségét, ezek kisebb fő́zdék számára való elérhetőségét kiemelten fontosnak tartják. Ezekkel megvalósítható lenne a bérfőzdék számára is a kisléptékú technológiai fejlesztés, a minőségi pálinka előállítás irányába történő, már határozottan érzékelhetô elmozdulás gyorsítása.

A munkaszervezetek vezetői megerősítették, hogy a főzdék, turisztikai szolgáltatók és önkormányzatok/térségi együttmúködések tekintetében jelentôs együttmúködés nem tapasztalható. Kedvező jeleket már lehet tapasztalni a főzdék (és itt ismét jellemzően a kereskedelmi főzdék tekintetében) és néhány vendéglátóhely, turisztikai szolgáltató, esetenként egy-egy önkormányzat közt, ezt azonban még bőven fejlesztésre szoruló terület. A tapasztalatok alapján mindenképpen lehet szélesebb területi hatásról beszélni, mivel a főzdék bevételén, az ott biztosított munkahelyeken túlmenően, az előállított termékből származó haszon, a turizmuson, helyi gazdaságon keresztül „leszivárog” a környező települések termelői, lakói, vállalkozói számára is. A jó minőségű helyi hungarikum-termék egyértelműen hozzájárul a térség reklámjához, a térség többi termékének és attrakciójának a népszerūsítéséhez. Kiemelték még azt is, hogy a gönci barackpálinka hozzájárul a helyi identitástudat erősítéséhez, a helyi közösség értékeinek ápolásához, a helyi közösség fejlődéséhez.

\section{A bungarikum megitélése}

A hungarikumok megítélését az összes megkeresett szereplőtől megkérdeztük, így az itt következő eredményekben az összes interjú-alany véleménye bele van foglalva. A gönci barackpálinka ismertségének feltérképezésekor külön lett választva a belföldi és a hazai ismertség (4. ábra), mivel feltételezhető volt, hogy a kettő között különbséget lehet találni. A válaszadók egy négyes skálán (nem ismert, kis mértékben ismert, viszonylag ismert, mindenki ismeri), saját véleményük alapján helyezhették el a hungarikum terméket. A feltételezés beigazolódott, mivel a válaszok alapján a termék hazai ismertsége jóval nagyobb (gyakorlatilag a válaszadók véleménye szerint szinte mindenki ismeri), mint a külföldi (ahol a válaszadók véleménye szerint gyakorlatilag senki nem ismeri). 


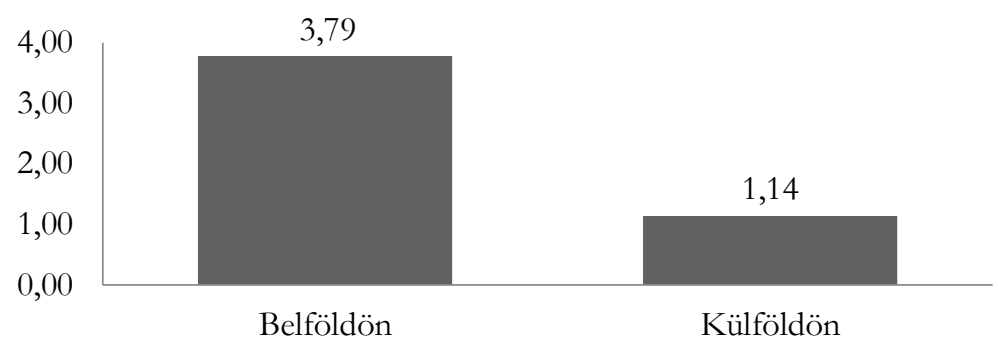

\section{4. ábra. A gönci barackpálinka átlagos ismertsége a megkérdezettek véleménye alapján Megjegyzés: 14 skálán, abol: 1) Nem ismert - 4) Mindenki ismeri Forrás: Saját kutatás (2014) és sžerkesztés, 2019}

Meg kell jegyezni ugyanakkor, hogy a térségbe először látogató, vagy beérkező vendégek, illetve a térségbe már nem először érkező, vagy elutazó vendégek vonatkozásában a megkérdezettek éles különbséget tettek, mivel utóbbi csoport már nagy valószínűséggel kapcsolatba került a vizsgált termékkel, így a gönci barackpálinka ebben a csoportban már jóval nagyobb ismertségi mutatóval rendelkezhet. A másik megjegyzendő, hogy a vizsgált térség határközelisége miatt, a szomszédos Szlovákiából érkező vendégek, valamint rajtuk keresztül összességében a szlovákok termék-ismertsége jóval határozottabb, és elkülöníthető az általános külföldi megítéléstől.

A gönci barackálinka hozzájárulását az országimázshoz nem konkrétan, mint „,gönci barack”, hanem mint jó „pálinka” vonatkozásában nevesítették a megkérdezettek. Ezt alátámasztja az is, miszerint a térségbe érkező külföldiek nem előbbit, hanem utóbbit, a jó pálinkát (és nem is feltétlenül a barackból készültet) keresik. Egytől négyig terjedő skálán a válaszadók gyakorlatilag mind egyes osztályzatot adtak konkrétan a gönci barackpálinka, illetve a rá fonódó turisztikai elemek iránti külföldi keresettség/ismertség vonatkozásában.

Arra a kérdésre, hogy maga a „hungarikum” kifejezés, mint „védjegy” jelent-e valamit a külföldi fogyasztónak, turistáknak, túlnyomó részt nemleges választ kaptunk. Általános vélemény szerint hungarikumnak számító dolgokról hallottak ugyan a külföldi látogatók (mint pl. a gulyás, paprika, pálinka általában stb.), de magáról a hungarikumról, mint egyfajta védjegyről nemigen tudnak. A gönci barackpálinkával kapcsolatban ezt mindenképpen meg lehet állapítani. Tehát nem keresik, illetve aki keresi, az sem azért keresi, mert a hungarikumok gyüjteményében szerepel, hanem csak azért, mert „pálinka”, és helyben megtalálható.

A gönci barackpálinka, mint hungarikum szélesebb értelemben vett területi hatásával minden válaszadó egyetértet. A vizsgálat eredményei alapján (5. ábra) ez a hatás még nem túl jelentős az érintett térség és lakói számára (csupán a megkérdezettek 4\%-a gondolta ennek ellenkezőjét), ugyanakkor olyan potenciált hordoz, ami a megkérdezettek közel háromnegyede $(73,91 \%)$ szerint az érintett terület gazdasági- és társadalmi fejlődéséhez érdemben hozzájárulhat. 


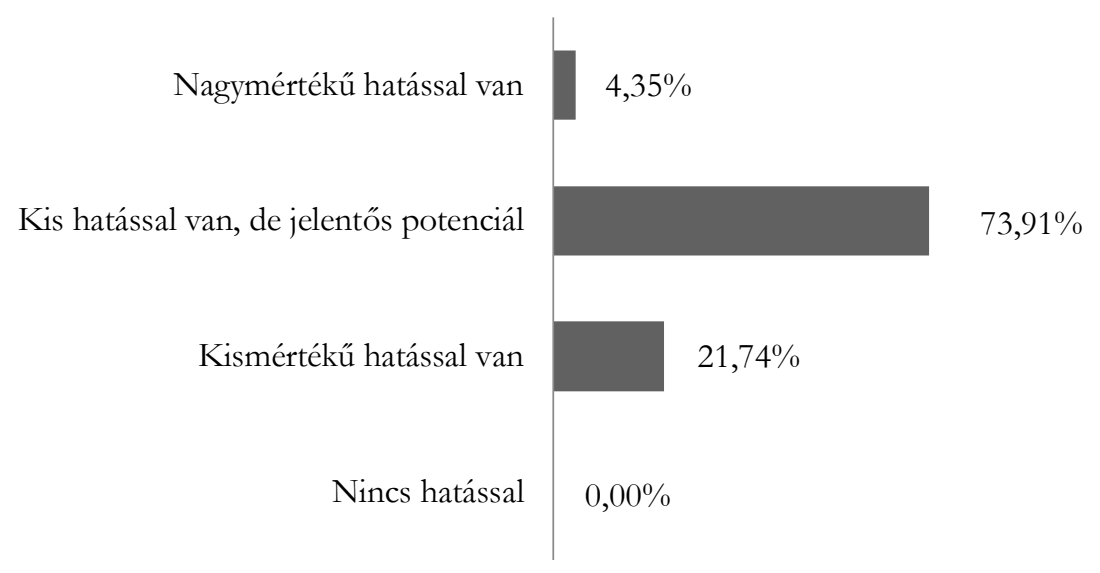

\section{5. ábra. A gönci barackpálinka térségre kifejtett hatásának megítélése a válaszadók véleménye alapján $(\%)$ \\ Forrás: Saját kutatás (2014) és szerkesztés, 2019}

\section{KÖVETKEZTETÉSEK ÉS JAVASLATOK}

A térségben lefolytatott kutatás teljes mértékben megerősítette, hogy a gönci barackpálinka joggal érdemelte ki a hungarikum „,védjegyet”, hiszen olyan sajátos erőforrást jelent, mely nemzetközi viszonylatban is különlegesnek számít. A terméket tekintve lehatárolhatók közvetlen, és közvetetten is jelentkező hasznok, melyek mind a termékpálya szereplőinek, mind a szélesebb értelemben vett térségnek a szempontjából is értelmezhetôk. A közvetett hasznok esetén először az alapanyag előállítókat kell megemlíteni, akik ha nem is feltétlen a pálinka elóállítás céljából foglalkoznak a kajszival, de adott százalékban a járulékos cefrézés, illetve a felvásárló piac elégtelensége esetén az alternatív felhasználás révén jutnak bevételhez. A pálinka előállítás másik pozitívuma lehet az is, hogy a pálinkában lévő gyümölcs értékesítése már húzható-halasztható, míg a friss gyümölcsé nem (ha sok a barack, alacsony a felvásárlási ár, a pálinka is több és olcsóbb lesz, viszont raktározhatóbb, és akár a következő évben is értékesíthető). A pálinka előállító bér- és kereskedelmi főzdék is közvetlen haszonhoz jutnak a főzetés és az értékesítés során, de ugyanez elmondható a nem előállító kereskedelmi szereplőkről, turisztikai szolgáltatókról, vendéglátóhelyekrôl is, bár itt a haszon már áttételesebb.

Közvetettként lehet még értelmezni az előbb felsoroltakon keresztül fenntartott, vagy bővített munkalehetőségeket is, valamint azt a hasznot, melyet a főzdék a munkahelyek teremtésén és az adókon keresztül a helyi önkormányzatoknak jelentenek. Itt már átérünk a térség számára nyújtott hasznossághoz, hiszen előbbiek végső soron egy település, térség prosperálásához nyújtanak hátteret, miközben jövedelemmel, bevétellel látják el a helyi lakosokat, szereplőket. A helyi termék előállítás, a helyi igények helyi produktumokkal való kielégítése mindenképpen előnyös adott lokalitás számára.

Mindenképpen ki kell emelni, hogy a gönci barackpálinka olyan minőségi reklámhordozót jelent, mely az egész térség gazdasági-, társadalmi folyamataira, fejlesztési lehetőségeire kihatással van. A térség többi adottságát kiegészítve hozzájárulhat azoknak a hátrányoknak 
az ellensúlyozásához, mérsékléséhez, melyek az egyébként kiemelkedő erőforrásokkal rendelkező, érintett térségeket az ország egyik legproblematikusabb térségévé teszi. A legfontosabb térségi hatások a válaszadók véleménye alapján összegezve az alábbiak:

- A főzdék bevétele;

- Helyi adóbevételek;

- Munkahely teremtés;

- Helyi alapanyag beszállítás - biztosabb értékesítés;

- Alternatív jövedelem és diverzifikációs lehetőség a helyi gazdálkodóknak;

- Helyi vendéglátás és turizmus serkentése/segítése;

- Gönci barackpálinka, mint védjegy hozzájárul a térség ismertségéhez, reklámozásához;

- A többi helyi termékre gyakorolt extern hatás.

Ahhoz, hogy a gönci barackpálinka, mint egyedi erőforrás még jobban kiaknázható legyen, számos észrevételt és javaslatot tettek, amiket annak fényében kell értékelni, hogy a vizsgálat óta eltelt időben ezek egy része már megvalósult. Az első helyen szerepelt annak a biztosítása, hogy a termőhelyi kapacitásokat lehetőség szerint teljesen használják ki. Nyilvánvaló, hogy a gönci barackpálinka nem tömegtermék, és az előállítás volumenének is megvannak a határai, ugyanakkor számos gazdálkodó, termelő számára nyújthatna még megélhetést.

A kisebb, csak bérfőzést végzô elöállítók számára több lehetőséget kellene teremteni a tevékenységük gazdaságosabbá tételéhez, kisebb volumenű (pár millió forintos) támogatások, fejlesztési források biztosításához/eléréséhez, illetve tevékenységük kereskedelmi, turisztikai célú kibővítéséhez. A szabályozottságon való változtatást, könnyítést a megkérdezettek háromnegyede emelte ki, mint a lehetőségek jobb kiaknázásához szükséges lépést.

Mindemellett, a termelőknél, főzdéknél termelődő közvetlen hasznon túl, a gönci barackpálinka turisztikai lehetőségeinek a kiaknázása nyújt, nyújthat még további lehetőségeket. A termék, mint hungarikum már eleve egy olyan minőséget és értéket képvisel, mely mind magában a gasztronómiai felhasználásban, mind pedig a köré szerveződő kínálati elemeken, rendezvényeken, a szélesebb értelemben vett térségi turizmuson keresztül szivárogtathatja le hatásait az érintett településekre.

Felmerült az igény egy olyan független szervezet vagy személy irányában, aki a gönci barackpálinka köré fonódó termelést, értékesítést, marketinget, turizmusszervezést összefogja, koordinálja, elősegíti. Érdekes, hogy a térségben található turisztikai szervezetek, összefogások, az érintett akciócsoportok ezt a feladatot még nem vállalták fel, annak ellenére, hogy a termékben rejlő potenciálokkal teljesen tisztában vannak. Az önálló gazdasági érdekeltséggel rendelkező főzdék együttműködése ezen a téren nyilvánvalóan nem egy egyszerű feladat, ugyanakkor az érintettek körében is felmerülő igény kiszolgálása, és egy tudatos stratégia sokat lendíthet a térség és a térségi szereplők helyzetén. 
Az elégedett vendég a legjobb reklám. A gönci barackpálinkát a többi kiemelkedő helyi termék és turisztikai attrakció közös mixében lehetne még jobban felhasználni, ami vonatkozik mind az adott térség turisztikai kínálatára, mind pedig az országimázsban való felhasználhatóságra is.

Ahhoz, hogy mi kéne a gönci barackpálinka országimázshoz való hatékony hozzájárulásához, első helyen mindenki a „több pénz”-t emelte ki. Emellett konkrétabb javaslatként a reklám fontosságát, a térségi szintû stratégia kidolgozását és múködtetését, egy szervezet vagy személy által összefogott kooperáció megvalósítását, és a határozottabb állami szerepvállalást nevesítették. A marketing, a média, a népszerūsítés szerepe elengedhetetlen.

\section{FELHASZNÁLT IRODALOM}

Belletti, Giovanni - MAResCotTi, Andrea - SCARAmuzzi, Silvia (2003). Paths of rural development based on typical products: a comparison between alternative strategies. In: Cristovao, Artur. Omodei, Luigi Zorini (Eds.): Farming and rural systems research and extension - Local identities and globalisation. Fifth IFSA European Symposium Florence. Firenze: ARSIA pp. 384-395.

Bretagnolle, Vincent - Berthet, Elsa - Gross, Nicolas - Gauffre, Bertrand - Plumejeaud, Christine - Houte, Sylvie - Badenhausser, Isabelle - Monceaua, Karine - Allier, Fabrice MoneSTIEZ, Pascal - GABA, Sabrina (2018): Towards sustainable and multifunctional agriculture in farmland landscapes: Lessons from the integrative approach of a French LTSER platform. Science of the Total Environment 627 pp. 822-834. https://doi.org/10.1016/j.scitotenv.2018.01.142.

Chesire, Paul C. (2003): Territorial competition: lessons for (innovation) policy. pp. 331-346 In: Bröcker, Johannes - Dohse, Dirk - Soltwedel, Rüdiger (Ed.): Innovation clusters and interregional competition. Heidelberg: Springer

EC (2005): 1698/2005/EK - A Tanács rendelete (2005. szeptember 20.) az Európai Mezőgazdasági Vidékfejlesztési Alapból nyújtandó vidékfejlesztési támogatásról. OJ L 277 (2005. 10. 21). Európai Közösségek, Luxemburg

lex.europa.eu/LexUriServ/site/hu/oj/2005/1 277/1 27720051021hu00010040.pdf

ENDRIGHI, Emiro. (1999): La valorizzazione delle produzioni tipiche locali. Dal concetto di valore alle indicazioni operative. (The valorisation of typical local products. From the concept of value to the operative indications). Rivista di Economia Agraria LIV (1) pp. 3-26

KÁPOSZTA József (2007): Regionális gazdaságtan. Gödöllő: SZIE GTK

KULCSÁR László (2017): A vidékfejlesztés elméleti megközelítése: regionális és kulturális összefüggések. Kolozsvár: Kriterion

LENGYEL Imre (2003): Verseny és területi fejlődés: térségek versenyképessége Magyarországon. Szeged: JATEPress

MARSDEN, Terry - SonNINO, Roberta (2008): Rural development and the regional state: Denying multifunctional agriculture in the UK. Journal of Rural Studies Vol. 24.(4) pp. 422-431 https://doi.org/10.1016/j.jrurstud.2008.04.001

MuRDOCH, Jonathan (1993): Sustainable Rural Development: Towards a research agenda. Geoforum Vol. 24. (3) pp. 225-241 https://doi.org/10.1016/0016-7185(93)90018-D

Pacciani, Alessandro - Belletti, Giovanni - Marescotti, Andrea - SCARamuzZi, Silvia (2001): The role of typical products in fostering rural development and the effects of regulation (EEC) 2081/92. http://www.origin-food.org/pdf/partners/belmarscaparole.pdf 
RECHNitZer János - Tóth Tamás (2014): Territorial Competitiveness in Central and Eastern Europe. Journal of Business Administration Research Vol. 3. (1) pp. 96-106. https://doi.org/10.5430/jbar.v3n1p96

RiTTER Krisztián (2013): A hungarikumok szerepe a vidékfejlesztésben a 2014-2020-as vidékstratégia tükrében. In: Káposzta J. (Szerk.): A KKV-k szerepe és helyzete a gazdaságban és a Hungarikumok szerepe a területi fejlődésben és fejlesztésben. Gödöllő: SZIE, pp. 64-69.

RiTTER Krisztián (2017): A hungarikumok szerepe a vidékfejlesztésben Bátya példáján keresztül.

Studia Mundi - Economica 4. (4) pp. 69-82. ISSN 2415-9395 https://doi.org/10.18531/Studia.Mundi.2017.04.04.69-82

TERLuin, Ida J. - Post, Jaap H. (2001): Key messages on employment dynamics in leading and lagging rural regions of the EU. (Az „European Rural Development: Problems, Chances, Research Needs” c. konferencián (2001. május 7-9.) elhangzott előadás anyaga.) Agricultural Economics Research Institute LEI, The Hague http://www.iiasa.ac.at/Research/ERD/net/pdf/terluin 1.pdf

TóTH Bettina - NAGY Gyula - HeGEDÚs Gábor (2017): A helyi értékek és hungarikumok turisztikai attrakcióvá való fejlesztési lehetőségei alföldi példákon keresztül. Turisztikai és Vidékfejlesztési Tanulmányok (2) pp. 4-19.

TÓZSA István - ZÁTORI Anita (2013): Hungarikumok. [Corvinus Turizmus Kompetencia Központ Szakkönyvsorozat - 1.] Budapest: Budapesti Corvinus Egyetem GK KTI Turizmus Kompetencia Központ

TÖRÖK Áron (2013): Hungarikumok - Magyarország földrajzi árujelzői? Az eredetvédelem szerepe a XXI. századi mezőgazdaságban és élelmiszertermelésben - a pálinka példájának tanulságai. $\mathrm{PhD}$ értekezés. Budapest: Corvinus Egyetem

\section{Köszönetnyilvánítás}

A kutatás a „Pálinka mint hungarikum területi jelentösége Magyarországon” címú (HUNG624/2013. azonosítószámú) projekt keretében, a Vidékfejlesztési Minisztérium és a Hungarikum Bizottság támogatásával valósult meg. 
${ }^{18}$ 这 57
BGE 